\title{
Blockage of migration routes by dam construction: can migratory fish find alternative routes?
}

\author{
Rosimeire Ribeiro Antonio*, Angelo Antonio Agostinho*, Fernando Mayer Pelicice*, \\ Dayani Bailly*, Edson Kioshi Okada* and João Henrique Pinheiro Dias**
}

The present study explored the interaction between the upriver migration of fish and the blockage of their migration routes by dam construction. Specifically, we studied (i) the capacity of migratory fish to locate alternative routes in the presence of an obstacle, and (ii) the behavior of the fish after they were artificially transferred to the reservoir. With the use of the markrecapture technique (tagging), the study was carried out near Porto Primavera Dam (UHE Engenheiro Sérgio Motta) between 1994 and 1999, a period prior to the closure of the floodgates and the installation and operation of the fish pass facilities. The fish were caught in the dam forebay downstream, marked with LEA type tags, and released upstream (5113 individuals; 14 species) and downstream $(1491 ; 12)$ from the dam. The recaptures were carried out by local professional and amateur fishermen. A total of 188 individuals $(2.8 \%)$ were recaptured, mostly the curimba Prochilodus lineatus. Nearly half of the recaptures downstream occurred in tributaries, especially in the Paranapanema River, indicating that in the presence of an obstacle the fish are able to locate alternative migration routes. The remainder stayed in the main channel of the Paraná River, at a mean distance of less than $50 \mathrm{~km}$ from the release point. Of the fish released upriver from the dam, approximately half were recaptured downriver. Although the river was only partly dammed, the movement of the fish downriver suggests that they became disoriented after being transferred. Those that remained upriver avoided the reservoir and moved, rather rapidly, toward the lotic stretches farther upstream. From these results it is clear that, in the course of the decision process in installing fish passes, it is necessary to take into account the existence of spawning and nursery areas downriver and upriver from the reservoir.

O presente estudo visa explorar a interação entre a migração ascendente de peixes e a obstrução de vias migratórias, pela construção de barragens. Especificamente, foi estudada (i) a capacidade de peixes migradores em localizar rotas alternativas na presença de um obstáculo, e (ii) o comportamento dos peixes após serem transpostos artificialmente para o reservatório. Com o uso da técnica de marcação e recaptura, o estudo foi desenvolvido nas imediações da barragem da hidrelétrica de Porto Primavera, entre 1994 e 1999, período anterior à instalação e operação de mecanismos de transposição. Os peixes foram capturados a jusante, nas imediações da barragem, receberam marcas do tipo "LEA" e foram liberados a montante (5113 indivíduos; 14 espécies) e a jusante $(1491 ; 12)$ da barragem, sendo as recapturas realizadas por pescadores profissionais e amadores da região. No total, foram recapturados 188 indivíduos (2,8\%), a maioria de curimba Prochilodus lineatus. Praticamente metade das recapturas de jusante ocorreram em tributários, especialmente no rio Paranapanema, indicando que na presença de um obstáculo os peixes são capazes de localizar rotas alternativas de migração. O restante permaneceu na calha do rio Paraná, a uma distância média inferior a $50 \mathrm{~km}$ do ponto de soltura. Dos peixes liberados a montante da barragem, aproximadamente metade foi recapturado a jusante. Embora o rio estivesse parcialmente barrado na ocasião, a movimentação de peixes em direção a jusante sugere desorientação após a transposição. Aqueles que permaneceram a montante evadiram o reservatório rumo a trechos superiores (lóticos) mais distantes, desempenhando grandes velocidades. Com estes resultados fica claro que no processo decisório sobre a implantação de mecanismos de transposição é preciso considerar a existência de áreas de desova e desenvolvimento inicial a jusante e montante do reservatório.

Key words: Fish migration, Fish pass, Tagging, Paraná River, Porto Primavera Reservoir.

\footnotetext{
*Universidade Estadual de Maringá - UEM, Nupelia-PEA, Departamento de Biologia, Av. Colombo, 5790, Bloco H-90, 87020-900 Maringá, PR, Brazil. agostinhoaa@gmail.com

**Companhia Energética de São Paulo - CESP - Divisão de Conservação e Recuperação de Ecossistemas, Rodovia Marechal Rondon, km 667 (Usina Jupiá), 16920-000 Castilho, SP, Brazil. joao.dias@cesp.com.br
} 


\section{Introduction}

In the Paraná River basin, reproductive migrations of fish are relatively well-known seasonal phenomena (Godoy, 1967; Bonetto et al., 1981; Agostinho et al., 2003). During the reproductive period, which occurs in the months when both rainfall and river levels are highest (Summer), some species move upriver in search of suitable environments for spawning, traveling long distances toward lower-order tributaries. Of the more than 250 fish species catalogued in the Paraná River basin within the territory of Brazil, approximately 20 are longdistance migrators, many of them of large size (Resende, 2003; Agostinho et al., 2004).

Historically, large migratory fishes are among the most esteemed by the traditional, commercial, and sport fisheries of the region (Petrere Jr. et al., 2002). At present, however, this fishery is showing clear signs that the stocks are being depleted. This can be attributed to a group of factors, most prominently overfishing, occupation and incorrect use of the surrounding land, and especially the damming of the rivers (Agostinho et al., 2005; Okada et al., 2005).

Impoundments, in addition to altering the regional hydrological regime (intensity, period, and frequency of floods), and as a result interfering with the environmental triggers for gonadal maturation and spawning of fish (Vazzoler, 1996), constitute obstacles that interrupt and profoundly alter fish migration routes (Agostinho et al., 2005). Consequently, the existence of dams prevents the migratory species from reaching suitable spawning locations, which negatively impacts the annual population recruitment. The number of impoundments now existing in the main channel of the Paraná River and its principal tributaries, estimated at about 150 (Agostinho et al., 2007), makes plain the dimension of the problem.

In the absence of fish pass facilities (ladders and elevators), the degree of impact caused by a dam structure will depend on the ability and possibility of the fish to spawn in the immediate vicinity of the dam, or even to seek out remnant areas downstream. However, there are still many doubts about the flexibility of the migratory species in their spatial requirements for completing the reproductive cycle. An intriguing and recurrent question is related to the migration routes taken by the fish after they encounter the dam. It is not known if, upon encountering the barrier, the fish search for alternative routes (tributaries or other nearby rivers), or remain aggregated near the dam until they spawn or reabsorb their vitelline oocytes. Another important question refers to the behavior of those that succeed in passing the dam, when fish pass facilities exist. In this case, there are doubts about the capacity of the fish to continue their migratory movement. Although Agostinho et al. (1999) presented evidence that this is possible, empirical evidence is still scarce.

To clarify these questions, the present study analyzed mark and recapture data for some species of migratory fishes that concentrate downriver from Porto Primavera Hydroelectric Dam (Engenheiro Sérgio Motta power plant), Upper Paraná River Basin. The analyses were based on releases of tagged fish both above and below the obstacle. Specifically, we sought to explore aspects of the alternative migration routes for the fish tagged and released downriver from the dam, during a period when Porto Primavera was not provided with any fish pass facility. In addition, the study explored the behavior of the fish that entered into the reservoir, after being manually released above the barrier.

\section{Material and Methods}

\section{Study area}

The study region included the Itaipu and Porto Primavera (UHE Engenheiro Sérgio Motta) reservoirs and Jupiá Dam (UHE Engenheiro Souza Dias - Fig. 1). This area also included the Upper Paraná River floodplain, located between Porto Primavera Dam and the beginning of Itaipu Reservoir. This is the last remnant of the region with a long stretch of undammed river (see chapters in Thomaz et al., 2004). Different tributary rivers, such as the Ivinheima, Baia, Ivaí, Amambaí, Iguatemi and Piquiri, comprise the regional landscape and are used by species of migratory fishes as spawning environments (Nakatani et al., 2004). The plain also contains floodplain lakes, which the migratory species use for their initial development during the first years of life.

Before the closure of the Porto Primavera floodgates in December 1998, which flooded an area of $2044 \mathrm{~km}^{2}$, this floodplain extended over $480 \mathrm{~km}$. Mark and recapture experiments carried out during this period revealed fish displacements from Itaipu until the Verde River located in the upper part (Agostinho et al. 1994; Agostinho et al., 2003). After the construction of the reservoir, the wild stretch was reduced to $230 \mathrm{~km}$, and the hydrological regime was also considerably affected (Agostinho et al., 2004). Although the floodplain environments have a vital role as spawning and nursery areas (Gomes \& Agostinho, 1997), migratory fish still move in the direction of Porto Primavera Dam, probably toward the tributaries located upriver.

\section{Mark and recapture (tagging)}

The collections of fish were made immediately downstream from Porto Primavera Dam, at the border between the states of São Paulo and Mato Grosso do Sul. The fish were collected with cast nets, with a mesh size of $12 \mathrm{~mm}$ between adjacent knots.

A total of 6604 individuals belonging to 14 fish species were caught and tagged (Table 1). LEA type tags (a small PVC tube), numbered and bearing instructions for their return, were implanted in the dorsum of the individual fish. Of the total caught and tagged, 1491 fish were released downstream from the dam, and 5113 were released upstream. The species with the largest number of tagged individuals was Prochilodus lineatus (3716), followed by Rhinelepis aspera (891), Salminus brasiliensis (844), Brycon orbignyanus (481), Pterodoras granulosus (386), and Leporinus elongatus (124). Fewer than 100 individuals of each of the remaining species were tagged and released (Table 1). We tagged only adult fish for all species, based on their respective sizes of first maturation (Vazzoler, 1996). 
Table 1. Number of fish tagged and released in the regions downstream and upstream from the Porto Primavera Dam, during the period from 1994 to 1998.

\begin{tabular}{llcc}
\hline Species & Common name & Downstream & Upstream \\
\hline Brycon orbignyanus & Piracanjuba & 143 & 338 \\
Hemisorubim platyrhynchos & Jurupoca & 1 & 12 \\
Leporinus elongatus & Piapara & 26 & 98 \\
Leporinus macrocephalus & Piavuçú & 0 & 1 \\
Leporinus obtusidens & Piau & 23 & 53 \\
Pseudoplatystoma corruscans & Pintado & 12 & 20 \\
Pterodoras granulosus & Armado & 86 & 300 \\
Prochilodus lineatus & Curimba & 520 & 3197 \\
Zungaro zungaro & Jaú & 7 & 18 \\
Piaractus mesopotamicus & Pacu & 0 & 2 \\
Pinirampus pirinampu & Barbado & 2 & 3 \\
Rhinelepis aspera & Cascudo preto & 428 & 463 \\
Sorubim lima & Chinelo & 1 & 6 \\
Salminus brasiliensis & Dourado & 242 & 602 \\
\hline Total & & 1491 & 5113 \\
\hline
\end{tabular}

All the fish were marked and released between January and February of 1994, in the period when reproductive migrations occur. Because the present study sought to investigate alternative migration routes used by the migratory fish that arrive in the area of the dam, it is important to note that at that time, there were no fish pass facilities at this dam. It is also worth noting that, although the floodgates were closed only at the end of 1998, the dam structure had been completed since 1993, and the high turbulence of the Paraná River water that passed through the 16 openings $(15 \times 23 \mathrm{~m})$ prevented the fish from moving from downriver to upriver of the dam. The power plant's elevator was only put into operation in 1999-2000, and the temporary fish ladder in 2001-2002.

Recaptures were made between January, 1994 and March, 1999, by traditional and sport fishermen along the Upper Paraná River. The tags with the required information (species, tag number, standard length, and the date, locality, and municipality of recapture) were sent to the Nupelia-State University of Maringá.

\section{Data analysis}

For each individual tagged and recaptured, we noted locality and date of release, and the locality, municipality, and date of recapture. The stretch of river in which the fish was released and recaptured was categorized, i.e., downstream or upstream from Porto Primavera Dam. Because we lack detailed information about main or preferable migration routes, we mean by "alternative routes" those pathways chosen when the former is no longer suitable (e.g., blocked). To determine the alternative migration routes downstream from Porto Primavera Dam, the recapture localities in the following rivers were grouped: Paraná (PR), Paranapanema (PRP), Baía (BAI), Ivinheima (IVI), and Ivaí (IVA). Also, from the information for locality, municipality, and dates of release and recapture, we calculated the time (days) and the distance $(\mathrm{km})$ traveled by each fish. This information allowed us to calculate the mean fish velocity, as: Velocity $=$ distance $(\mathrm{km}) /$ time (days).

Only fish that had traveled more than $5 \mathrm{~km}$, a distance that could indicate the beginning of migratory movements, were included in the analyses. Also, fish recaptured more than 71 days after their release, a value defined based on the mean speeds and maximum distances recorded in the upriver movements, were not included in the computations. This criterion was used in order to minimize the probability that a fish had traveled farther and then returned to near the site where it was released, which would lead to erroneous inferences about its movement.

The movement of each fish was analyzed individually on a graph that related the time ( $\mathrm{x}$ axis) and the distance traveled (y axis), which allowed us to infer their speed downstream and upstream (Delfino \& Baigún, 1985; Agostinho et al., 1994). In this case, the data matrix also included only those fish that had traveled more than $5 \mathrm{~km}$; however, the time limit was 300 days, considering only those fish with a mean speed above 1 $\mathrm{km} /$ day.

\section{Results}

Of the 6604 fish tagged, only 188 (2.85\%), belonging to 14 species, were recaptured between 1994 and 1999. Of these, $131(1.98 \%)$ were caught in the first 300 days and had traveled at speeds of more than $1.0 \mathrm{~km} /$ day. Considering only recaptures within 71 days, 110 individuals (1.67\%) were recorded (Table 2). Excluding those that had moved less than $5 \mathrm{~km}$, a total of 80 fish $(1.21 \%)$, belonging to 7 species, were recaptured in the period (Table 2).

Table 2. Number of tagged, released and recaptured individuals downstream (Down) and upstream (Up) from the Porto Primavera Reservoir. In the recaptures, the number of individuals captured within the first 71 days after their release (outside parentheses) are differentiated from those individuals with periods less than 300 days and speeds above $1 \mathrm{~km} /$ day (between parentheses). The combinations Down-Down, Up-Down, and Up-Up indicate the release and recapture localities respectively.

\begin{tabular}{lccccccc}
\hline \multirow{2}{*}{ Species } & \multicolumn{2}{c}{$\begin{array}{c}\text { Tagged and } \\
\text { released }\end{array}$} & \multicolumn{2}{c}{$\begin{array}{c}\text { Recaptures } \\
(<5 \mathrm{Km})\end{array}$} & \multicolumn{3}{c}{ Recaptures $(>5 \mathrm{Km})$} \\
\cline { 2 - 8 } & Down & Up & Down & Up & Down-Down & Up-Down & Up-Up \\
\hline P. lineatus & 520 & 3197 & $13(22)$ & $8(17)$ & $21(18)$ & $20(16)$ & $24(29)$ \\
S. brasiliensis & 242 & 602 & $1(1)$ & & $2(2)$ & $1(1)$ & $4(6)$ \\
P. granulosus & 86 & 300 & $1(1)$ & $3(3)$ & $1(1)$ & & \\
L. elongatus & 26 & 98 & & $1(1)$ & $1(1)$ & $1(1)$ & $1(1)$ \\
B. orbignyanus & 143 & 338 & & & & $3(3)$ & $1(1)$ \\
P. corruscans & 12 & 20 & $1(2)$ & & & & \\
R. aspera & 428 & 463 & $1(1)$ & & & & $(1)$ \\
L. obtusidens & 23 & 53 & $1(2)$ & & & & \\
Total & 1480 & 5071 & $18(29)$ & $12(21)$ & $25(22)$ & $25(21)$ & $30(38)$ \\
\hline
\end{tabular}


Most of the recaptured individuals were curimba, $P$. lineatus ( 65 fish), with a $1.75 \%$ recapture rate, followed by the dourado $S$. brasiliensis $(7 ; 0.83 \%)$. Fewer than 5 individuals of each of the remaining species were recaptured. It should be emphasized that the curimba was the species with the highest number of individuals tagged and released, totaling 3717 fish.

A total of 50 fish were recaptured downstream, which had traveled more than $5.0 \mathrm{~km}$ and were recorded in the first 71 days. Of these fish, which belonged to 5 species, 25 had been released downstream, and 25 upstream (Table 3). Nearly half of the recaptures occurred in tributaries, especially the Paranapanema River ( $34 \%$ of the total). Other tributaries yielded fewer recaptures, such as the Ivinheima (3 fish), Baía (2) and Ivaí (2). We note that the movement into tributaries was more apparent in fish released downstream (64\%). The remaining recaptures occurred in the main channel of the Paraná River. The species with the highest number of captures was the curimba (Table 3 ), which totaled 41 individuals $(82 \%)$. The majority were recaptured in the main channels of the Paraná $(21 ; 42 \%)$ and Paranapanema $(16 ; 32 \%)$. The remaining species had low recapture rates.

Because of the low recapture rate of individuals of the other species, the following analyses consider specifically the data for the movements of the curimba P. lineatus. The spatial distribution of the recaptures of this species, for fish that had traveled more than $5.0 \mathrm{~km}$ and were recorded in the first 71 days, is shown in Fig. 1.

During the study period, the curimbas released were recaptured within a mean of 31 days $( \pm 2.55 \mathrm{SE})$, excluding movements after 71 days. Individuals released upstream tended to be recaptured after a longer time (Fig. 2a). From the release localities, the curimbas traveled a mean distance of $90 \mathrm{~km}( \pm$ $8.95 \mathrm{SE}$ ) until their recapture. Individuals recaptured downstream, independent of the release location, traveled over smaller distances than did those fish recaptured upstream (Fig. 2b), which traveled a mean distance of approximately $160 \mathrm{~km}$. This result indicates that the fish, once they arrived downstream from Porto Primavera, tended to remain at a mean

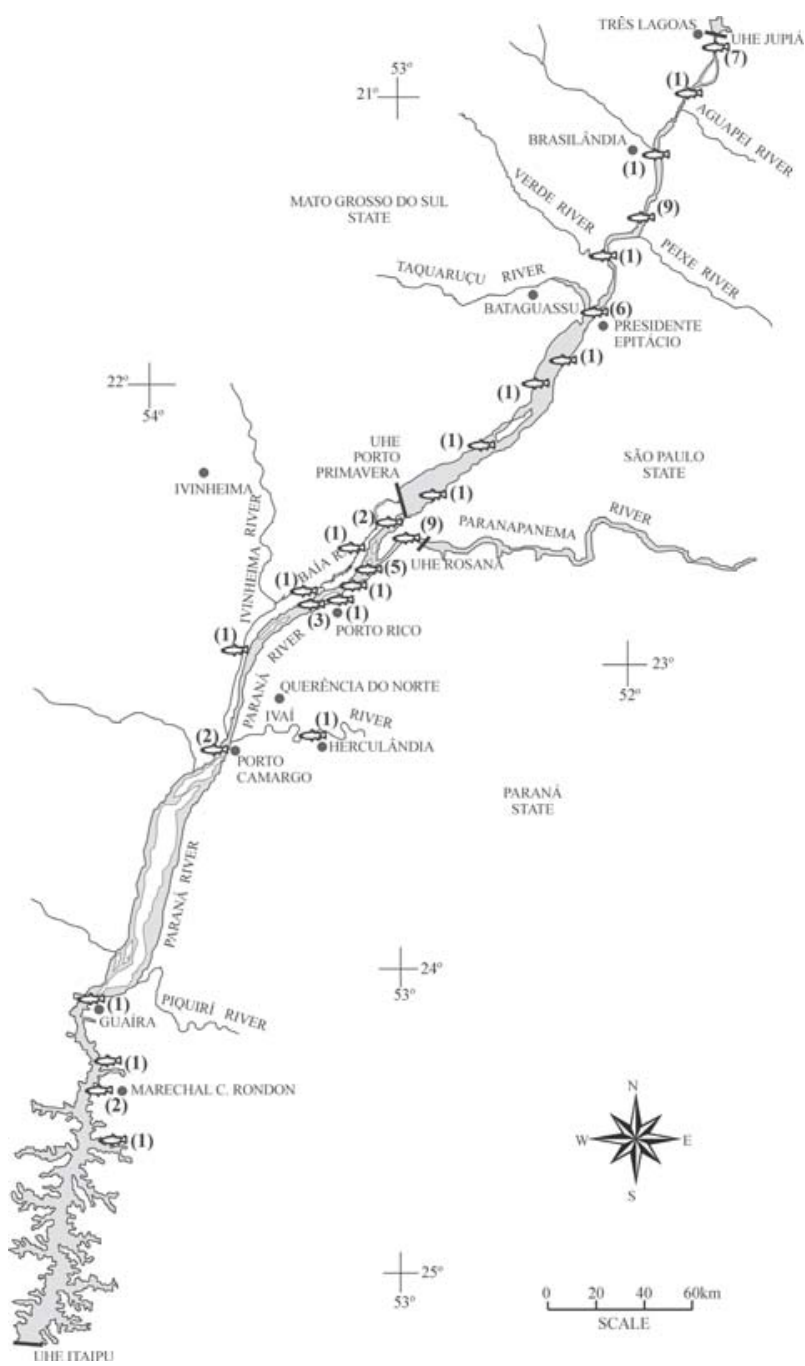

Fig. 1. Map of the study area, which includes the stretch of the Paraná River between the Jupiá and Itaipu reservoirs. Numbers between parentheses are the numbers of individuals of curimba (Prochilodus lineatus) recaptured in each place (details given in Results).

Table 3. Number of individuals recaptured downstream from the Porto Primavera Dam. $n=$ number of specimens; $P R=$ Paraná River; PRP = Paranapanema River; IVI = Ivinheima River; BAI = Baia River; IVA = Ivaí River. The combinations Down-Down and Up-Down indicate the release and recapture localities respectively.

\begin{tabular}{|c|c|c|c|c|c|c|c|c|c|c|c|}
\hline \multirow{2}{*}{ Attributes } & \multicolumn{2}{|c|}{ P. lineatus } & \multicolumn{2}{|c|}{ S. brasiliensis } & \multicolumn{2}{|c|}{ B. orbignyanus } & \multicolumn{2}{|c|}{ P. granulosus } & \multicolumn{2}{|c|}{ L. elongatus } & \multirow[t]{2}{*}{ Total } \\
\hline & $\mathrm{n}$ & $\%$ & $\mathrm{n}$ & $\%$ & $\mathrm{n}$ & $\%$ & $\mathrm{n}$ & $\%$ & $\mathrm{n}$ & $\%$ & \\
\hline \multicolumn{12}{|c|}{ Down-Down } \\
\hline $\mathrm{PR}$ & 8 & 38.09 & 1 & 33.33 & & & & & & & 9 \\
\hline PRP & 11 & 52.38 & & & & & & & 1 & 100 & 12 \\
\hline IVI & 1 & 4.76 & & & & & & & & & 1 \\
\hline BAI & 1 & 4.76 & 1 & 33.33 & & & & & & & 2 \\
\hline IVA & & & & & & & 1 & 100 & & & 1 \\
\hline total & 21 & & 2 & & & & 1 & & 1 & & 25 \\
\hline \multicolumn{12}{|l|}{ Up-Down } \\
\hline PR & 13 & 65.0 & 1 & 100 & 2 & 66.66 & & & 1 & 100 & 17 \\
\hline PRP & 5 & 25.0 & & & & & & & & & 5 \\
\hline IVI & 1 & 5.0 & & & 1 & 33.33 & & & & & 2 \\
\hline \multicolumn{12}{|l|}{ BAI } \\
\hline IVA & 1 & 5.0 & & & & & & & & & 1 \\
\hline total & 20 & & 1 & & 3 & & & & 1 & & 25 \\
\hline
\end{tabular}


distance of less than $50 \mathrm{~km}$ from the dam in the first 71 days. On the other hand, the fish that were released upstream and that did not return downstream, tended to seek the upper areas of the reservoir, remaining at some distance from the dam.

The mean velocity of the fish was estimated at $4.6 \mathrm{~km} /$ day $( \pm 0.53 \mathrm{SE})$. The fish recaptured upstream tended to show a mean velocity higher than those located downstream (Fig. 2c). Note, however, that in the latter segment the speeds of the fish varied widely (Fig. 2c). The fish released upstream and recaptured downstream showed the lowest mean speed of travel.

Analyzing the movements of individual specimens of curimba, one notes that all the fish recaptured upstream from the dam had traveled a minimal distance of $110 \mathrm{~km}$ in up to 300 days (Fig. 3). Of these, the majority traveled a distance between 170 and $250 \mathrm{~km}$ upstream, many in less than 90 days, which indicates high speeds. In a different pattern, the majority of the fish recaptured downstream, independent of the release locality (downstream or upstream), tended to move over smaller distances $(<75 \mathrm{~km})$; the majority traveled distances less than $60 \mathrm{~km}$ (Fig. 3). With the exception of a single individual that traveled $285 \mathrm{~km}$ in less than 30 days (recaptured in the Municipality of Porto Mendes, state of Paraná, Itaipu Reservoir), all those that traveled more than $230 \mathrm{~km}$ took longer than 180 days to be recaptured, which indicates that they moved more slowly.

\section{Discussion}

In spite of the low percentage of recaptures, and although they were essentially limited to one species (the curimba $P$. lineatus), the results of the present study elucidate some aspects of the interaction between dam construction and the movements of the large migratory fishes of South America. These results gain importance in view of the scarcity of knowledge of the behavior of these fishes in a scenario in which all the great rivers of the continent are already dammed or are in the process of being dammed (Agostinho et al., 2007).

Recaptures downstream from the dam indicate that a considerable percentage of migratory fishes, especially the curimba, on encountering this obstacle tend to move toward nearby tributaries. In this manner, although approximately half of the downstream recaptures occurred in the main channel of the Paraná River (generally at distances less than 60 $\mathrm{km}$ ), the other half of the fish succeeded in locating tributaries, especially the Paranapanema River which is closest to Porto Primavera Dam. These observations are important, because they indicate certain flexibility in the reproductive behavior, showing that at least part of the shoal is capable of changing their migration route after contacting the obstacle. This behavior is fundamental, since it can assure the reproduction and the perpetuation of populations even in situations in which principal migration routes are lost. Some recent studies have supported this trend, and reported that Prochilodus argenteus can successfully use tributaries down- stream from Três Marias Dam (São Francisco River basin) for spawning (Sato et al., 2005; Godinho \& Kynard, 2006). In addition, Godinho \& Kynard (2006) also report the existence of different populations living in a short river stretch $(\sim 50 \mathrm{~km})$, using distinct migratory routes for spawning. These findings highlight how complex migratory patterns of Neotropical fishes are. Thus, future studies in the Paraná River Basin could explore if $P$. lineatus individuals migrating upriver be-
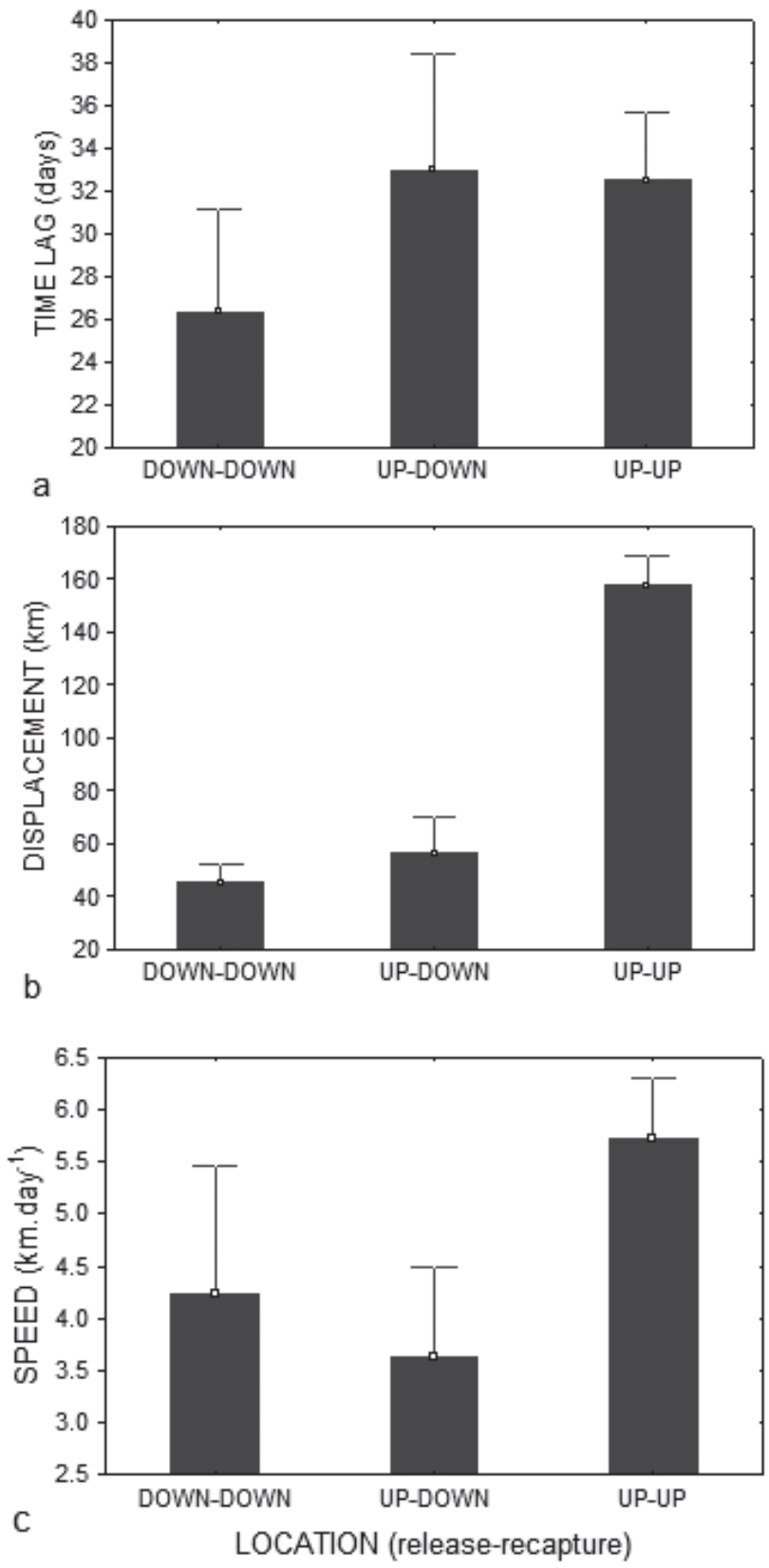

Fig. 2. Mean ( \pm SE) of release-recapture time lag (a), distance traveled (b) and speed developed (c) by individual curimba Prochilodus lineatus in the Upper Paraná River region, tagged and released downstream (Down) and upstream (Up) from the Porto Primavera Dam. Location indicates, respectively, the "release point - recapture point" in relation to the Porto Primavera Dam. 
long to multiple populations, if they have preferences for particular routes, and how Porto Primavera Dam has disrupted these patterns.

The relatively high recapture rate in the lower Paranapanema River, although it provides indications that migratory species are capable of locating alternative routes, does not indicate the effectiveness of spawning and the success of recruitment. Also in this river, where a series of reservoirs is present, migratory routes are interrupted by the first dam in the sequence (Rosana Reservoir), located less than 30 $\mathrm{km}$ from its mouth. It appears to be more difficult for the fish to locate the tributaries farther from the dam, seeing that only

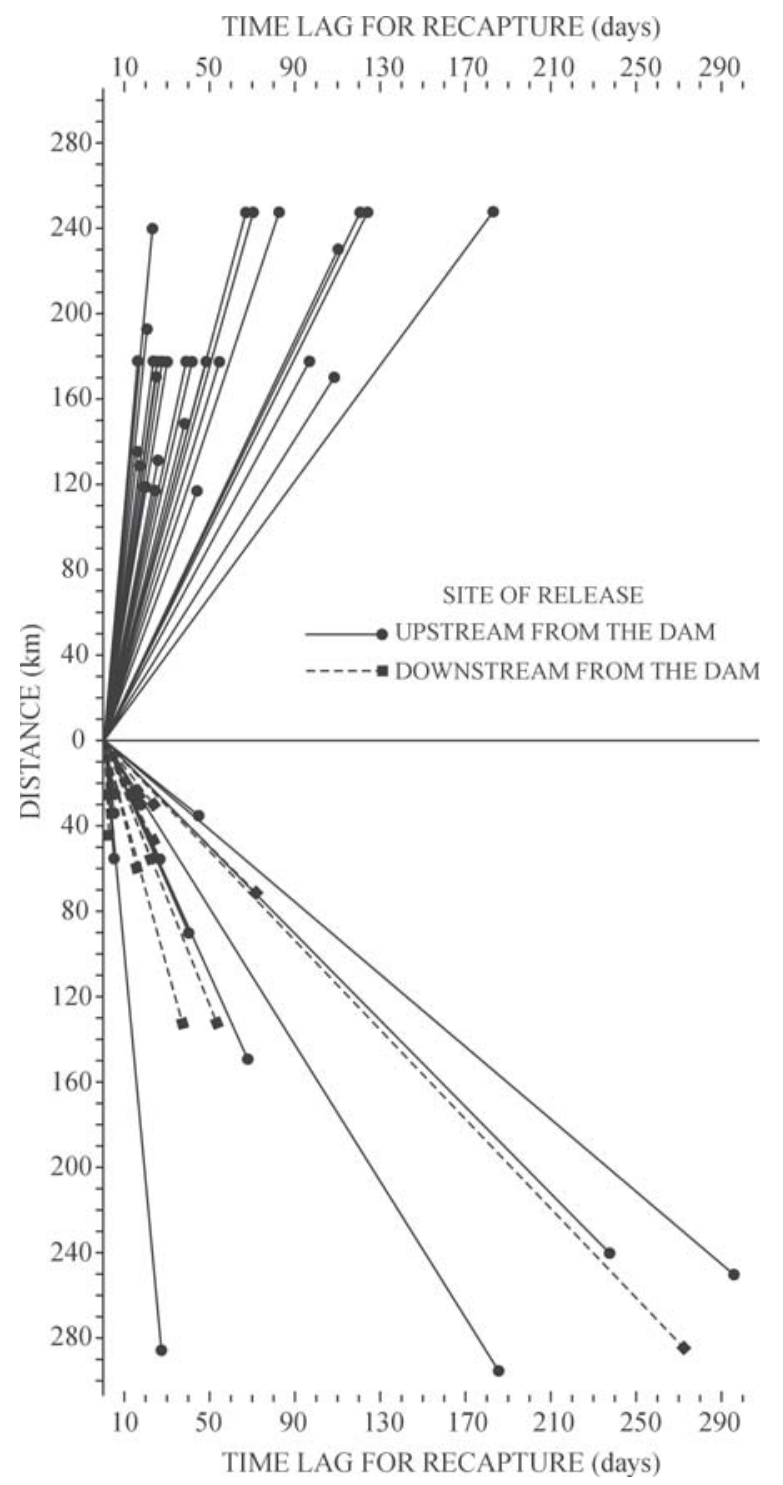

Fig. 3. Relationship between the time of recapture (days) and the movement $(\mathrm{km})$ of individuals of the curimba P. lineatus, after the fish were caught and tagged near the Porto Primavera Dam. The movements above the $0 \mathrm{~km}$ axis represent upstream movements, and movements below the axis indicate downstream travels. The release locality of the fish is indicated in the figure (downstream or upstream).
$14 \%$ of the downstream recaptures occurred in the Ivinheima, Baía and Ivaí rivers, which are located between 60 and $120 \mathrm{~km}$ from Porto Primavera Dam. It is worth emphasizing, on the other hand, that these data may underestimate this flow, in view of the prohibition on fishing with gillnets in the tributaries, which are appropriate for catching curimba. Anyway, if the fish concentrate near Porto Primavera Dam or even in the Paranapanema River for an extended time, the delay in spawning may result in re-absorption of the mature oocytes (Agostinho et al., 1993).

Of the curimbas released and recaptured upstream, a situation that simulates the artificial fish passes, the results clearly demonstrate that these fish seek to avoid the impounded regions in their reproductive period, moving toward upstream as well as downstream regions. The higher mean speed of travel observed upstream from the dam indicates that the fish are capable of reaching the higher reaches of the reservoir after they are transferred. This movement is probably linked to their recognition of the impoundment environment as unfavorable for spawning, stimulating more rapid migration upstream. Agostinho et al. (1994) observed a similar pattern for the armado Pterodoras granulosus in the Itaipu Reservoir. These authors, also working with mark-recapture experiments, reported that the transferred fish make their ascending migrations more quickly than do the fish present in the body of the reservoir. In Santa Clara Reservoir on the Mucuri River, located at the boundary of the states of Minas Gerais and Bahia, Pompeu (2004) also observed that some species did not show problems in traversing the region influenced by the reservoir, toward lotic regions upstream.

It is worth emphasizing, however, that $50 \%$ of the fish recaptured downstream were released upstream from the dam. There exists, therefore, an important percentage of fish that, after being transferred, did not proceed with the upriver migration. These results indicate that the fish were somewhat disoriented upon arriving in the lentic environment, and migrated in different directions. Obviously, these results have implications for the effectiveness of fish pass facilities, which, in general, release the fish near the water uptake by the turbines or spillway. At the time of this study, these structures had not been installed at Porto Primavera, but it is expected that when they are functioning, passage through dam components renders those individuals transferred to the reservoir more vulnerable to injury or death (Cada et al., 1997). The few studies of the efficiency of fish passes have basically sought to determine the number of fish passed and their selectivity (Agostinho et al., 2002; Oldani \& Baigún, 2002; Fernandez et al., 2004; Agostinho et al., 2007b, this volume), but there is only sparse information about what happens to the individual that is released upstream.

All the observed patterns refer basically to the behavior of the curimba $P$. lineatus, because this was the species recaptured in highest numbers. On the other hand, the results found in the present study are not conclusive in relation to other species, and the information in the literature is still limited. Delfino \& Baigún (1985) observed, however, that spe- 
cies of large migratory catfishes in the Uruguay River traveled shorter distances and at slower speeds, compared to species of Characiformes. Thus, it would be necessary to investigate if these species also have the skill to locate alternative migration routes, or the ability to make long journeys in unfavorable situations for migration, common in the impounded areas (e.g., low water velocity, turbidity, and oxygen).

Finally, based on the results obtained in this study, we can infer that: (i) in the eventuality that they do not travel up the reservoir, some fish can seek out alternative migration routes in the tributaries downstream, especially in the rivers close by; and (ii) although the individuals transferred upstream from dams rapidly reach higher stretches of the reservoirs, an important percentage moves back downstream, passing through turbines or the spillway, with implications for their physical integrity. With this information, it becomes obvious that an adequate understanding of the natural spawning areas and nurseries used by large migratory species must precede the construction or even the functioning of any fish pass facility. If critical areas are lacking upstream from the dam, there is the risk that these installations will act as a source of impacts. Moreover, considering that the fish can seek alternative migration routes downstream, indiscriminate or uncontrolled transfers should be avoided, especially if the downstream river stretch contains appropriate habitats for spawning and initial development.

\section{Acknowledgement}

We deeply thank João Dirço Latini for helping during the capture and tagging, Dr. Horácio Ferreira Julio Jr. for identifying the localities of recaptures, Dr. Luiz Carlos Gomes for reviewing the manuscript, and Jaime Luiz Lopes Pereira for preparing the figures. We also thank Nupelia-State University of Maringá for the financial and logistic support.

\section{Literature Cited}

Agostinho, A. A., J. R. Borghetti, A. E. A. de M. Vazzoler \& L. C. Gomes. 1994. Itaipu Reservoir: impacts on the ichthyofauna and biological bases for its management. Pp. 135-148. Proceedings of the environmental and social dimensions of reservoir development and management in the La Plata River Basin. Nagoya, Japan, UNCRD Research Report Series, 4, 157p.

Agostinho, A. A., L. C. Gomes, D. R. Fernandez \& H. I. Suzuki. 2002. Efficiency of fish ladders for neotropical ichthyofauna. River Research and Applications, 18: 299-306.

Agostinho, A. A., L. C. Gomes \& F. M. Pelicice. 2007a. Ecologia e Manejo de Recursos Pesqueiros em Reservatórios do Brasil. Maringá, EDUEM, 501p.

Agostinho, A. A., L. C. Gomes, H. I. Suzuki \& H. F. Júlio Jr. 2003. Migratory fish from the upper Parana river basin, Brazil. Pp. 19-98. In: Carolsfeld J., B. Harvey, C. Ross \& A. Baer (Eds). Migratory fishes of South America: biology, social importance and conservation status. Victoria, World Fisheries Trust, The World Bank and The International Development Research Centre, 372p.
Agostinho, A. A., V. P. Mendes, H. I. Suzuki \& C. Canzi. 1993. Avaliação da atividade reprodutiva da comunidade de peixes dos primeiros quilômetros a jusante do Reservatório de Itaipu. Revista UNIMAR, 15: 175-189.

Agostinho, A. A., L. E. Miranda, L. M. Bini, L. C. Gomes, S. M. Thomaz \& H. I. Suzuki. 1999. Patterns of colonization in neotropical reservoirs, and prognoses on aging. Pp. 227-265. In: Tundisi, J. G. \& M. Straskraba (Eds). Theoretical reservoir ecology and its applications. São Carlos, Backhuys Publishers, Brazilian Academy of Sciences, 585p.

Agostinho, A. A., S. M. Thomaz \& L. C. Gomes. 2004. Threats for biodiversity in the floodplain of the Upper Paraná River: effects of hydrological regulation by dams. Ecohydrology \& Hydrobiology, 4(3): 255-268.

Agostinho, A. A., S. M. Thomaz \& L. C. Gomes. 2005. Conservation of the biodiversity of Brazil's inland waters. Conservation Biology, 19: 646-652.

Agostinho, C. S, A. A. Agostinho, F. M. Pelicice, D. A. A. Almeida \& E. E. Marques. 2007b. Selectivity of fish ladders: a bottleneck in Neotropical fish movement. Neotropical Ichthyology, 5(2): 205-213.

Bonetto, A. A., M. Cânon-Veron \& D. Roldan. 1981. Nuevos aportes al conocimiento de las migraciones de peces en el Río Paraná. ECOSUR, 8(16): 29-40.

Cada, G. F., C. C. Coutant \& R. R. Whitney. 1997. Development of biological criteria for the design of advanced hydropower turbines. Idaho Falls, U.S. Department of Energy, Idaho Operations Office (DOE/ID-10578), 85p.

Delfino, R. \& C. Baigún. 1985. Marcaciones de peces en el embalse de Salto Grande, río Uruguay (Argentina-Uruguay). Revista de la Asociación de Ciencias Naturales del Litoral, 16(1): 85-93.

Fernandez, D. R., A. A. Agostinho \& L. M. Bini. 2004. Selection of an experimental fish ladder located at the dam of the Itaipu Binacional, Brazil. Brazilian Archives of Biology and Technology, 47(4): 579-586.

Godinho, A. L. \& B. Kynard. 2006. Migration and spawning of radiotagged zulega Prochilodus argenteus in a dammed Brazilian river. Transactions of the American Fisheries Society, 135: 811-824.

Godoy, M. P. 1967. Dez anos de observação sobre a periodicidade migratória de peixes do rio Mogi Guaçu. Revista Brasileira de Biologia, 27: 1-12.

Gomes, L. C. \& A. A. Agostinho. 1997. Influence of the flooding regime on the nutritional state and juvenile recruitment of the curimba, Prochilodus scrofa, Steindachner, in Upper Paraná River, Brazil. Fisheries Management and Ecology, 4(4): 263-274.

Nakatani, K., A. Bialetzki, G. Baumgartner, P. V. Sanches \& M. C. Makrakis. 2004. Temporal and spatial dynamics of fish eggs and larvae. Pp. 293-308. In: Thomaz, S.M., A. A. Agostinho \& N. S. Hahn. (Eds). The Upper Paraná River and its floodplain: physical aspects, ecology and conservation. Leiden, Backhuys Publishers, 393p.

Okada, E. K., A. A. Agostinho \& L. C. Gomes. 2005. Spatial and temporal gradients in artisanal fisheries: a case study of the Itaipu Reservoir, Brazil. Canadian Journal of Fisheries and Aquatic Sciences, 62: 714-724.

Oldani, N. O. \& C. R. M. Baigún. 2002. Performance of a fishway system in a major South American dam on the Paraná River (Argentina-Paraguay). River Research and Applications, 18(2): 171-183.

Petrere Jr., M., A. A. Agostinho, E. K. Okada \& H. F. Júlio Jr. 2002. Review of the Fisheries in the Brazilian Portion of the Paraná/ Pantanal basin. Pp. 123-143. In: Cowx, I. (Ed). Management 
and Ecology of Lake and Reservoir Fisheries. London, Fishing News Books, 416p.

Pompeu, P. S. 2004. Estudo da regra operativa e avaliação de um mecanismo de transposição de peixes do tipo elevador com caminhão tanque. Unpublished Ph.D. Dissertation. Centro de Pesquisas Hidráulicas e Recursos Hídricos da Escola de Engenharia da UFMG, Belo Horizonte, 103p.

Resende, E. K. 2003. Migratory fishes of the Paraguay-Paraná basin, excluding the Upper Paraná basin. Pp. 99-156. In: Carolsfeld J., B. Harvey, C. Ross \& A. Baer (Eds). Migratory fishes of South America: biology, social importance and conservation status. Victoria, World Fisheries Trust, The World Bank and The International Development Research Centre, 372p
Sato, Y., N. Bazzoli, E. Rizzo, M. B. Boschi \& M. O. T. Miranda. 2005. Influence of the Abaeté River on the reproductive success of the neotropical migratory teleost Prochilodus argenteus in the São Francisco River, downstream from the Três Marias Dam, southeastern Brazil. River Research and Applications, 21: 939-950.

Thomaz, S. M., A. A. Agostinho \& N. S. Hahn (Eds). 2004. The Upper Paraná River and its Floodplain: physical aspects, ecology and conservation. Leiden, Backhuys Publishers, 393p. Vazzoler A. E. A. de M. 1996. Biologia e Reprodução de Peixes Teleósteos: teoria e prática. Maringá, EDUEM, 169p.

Received January 2007 Accepted June 2007 